\title{
Exploring Relationships between Products Characteristics and B2C Interaction in Electronic Commerce
}

\author{
Karin Axelsson ${ }^{1}$ \\ ${ }^{1}$ Linköping university, Department of Management and Engineering, SE-581 83 Linköping, Sweden, \\ karin.axelsson@liu.se
}

Received 21 January 2008; received in revised form 21 April 2008; accepted 15 June 2008

\begin{abstract}
The main purpose of the paper is to explore and discuss the influence of product type on customer interaction in electronic commerce. We have conducted two qualitative case studies in distance selling companies to inductively explore how the product characteristics of garments and music-CDs influence customer interaction. We apply a product classification scheme built on product theory to characterize and classify these products. By classifying product types according to this scheme we focus certain aspects; e.g., in which situation the customer uses the product and, thus, experiences potential satisfaction. By applying product theory to the electronic commerce context we are expanding this theory into a new area. Knowledge about product characteristics' influence on customer interaction in various phases of electronic commerce enriches and specifies the existing product theory. In order to put this theory contribution into practice, a set of focal questions with the aim to increase product understanding in an electronic commerce setting is formulated. The questions highlight product related issues that are important to consider when deciding communication media in electronic commerce.
\end{abstract}

Key words: Product classification, Product theory, Customer communication media, B2C interaction, Distance selling, Electronic commerce 


\section{Introduction}

Imagine this scenario; a customer wants to order a blue velvet skirt on Internet but she is not sure whether the colour is exactly the nuance she is looking for. And how about the fabric, is the textile really as smooth as it looks on the screen? Will "medium" be the right size or should she order "large" instead? A couple of blocks away, another customer is about to order a music-CD on Internet. He has found a CD of his favourite singer, which he has been searching for a long time. Now he just has to place the order and wait for the delivery.

In this simple example of two distance selling (i.e., electronic commerce) settings there are of course several similarities between the customers' situations. Both might be wondering how long the delivery will take, how to return the product, if the product is kept in stock, etc. Nevertheless, the example also illustrates important differences between the two situations depending on what type of product the customer wants to buy. In this case, it is obvious that the "skirt customer" has to find answers to more product related questions before ordering compared to the "CD customer". When a company offers its products on distance from the customers, the traditional face-to-face communication has to be replaced by other ways of communicating. The company has to decide through which communication media the customer interaction should be conducted. Such decisions might be made with several purposes; e.g., to be cost-effective and offer automated communication media, or to compete with a high degree of customer service and, thus, offer many manually handled communication media that allow personal customer contact.

Several studies indicate that satisfied customers tend to become loyal to the company, which render long-term profitability, e.g., [3], [16], [37]. Providing customer service of high quality is even more important in distance selling than in physical business settings (face-to-face), according to some studies [34]. In order to establish long-term customer relationships, companies have to communicate with their customers. For distance selling companies this means that they have to offer communication media that the customers appreciate, in order for them to become satisfied [4]. Before the Internet era, customer communication in distance selling companies was mainly performed by telephone or mail. Nowadays, these companies have much more alternatives for their customer interaction, which implies more opportunities to establish long-term relationships [19], [40]. This new situation also means that the choices of communication media has become an important issue for distance selling companies. Therefore, it is critical to learn more about different communication media, both from a customer and a company perspective.

In this paper, we explore the importance of the product type and its implications for business-to-consumer (B2C) interaction in electronic commerce. As the example above shows, different types of products give rise to various customer questions, both before, during, and after an order is placed. This is important to consider when deciding which communication media to offer customers and which business actions that should be possible to perform through a certain medium. Unfortunate decisions concerning which communication media a company offers its customers, could result in mismatches between the company's and the customers' preferences. Such mismatches might obviously in the long run be threatening against the company's presence. We try to confront this problem by discussing product type as an important feature when choosing B2C communication media in electronic commerce settings.

The main purpose of the paper is to explore and discuss the influence of product type on customer interaction in electronic commerce. We do this by applying a product classification scheme from Goldkuhl and Röstlinger [12] to our empirical findings. In their product classification scheme, Goldkuhl and Röstlinger propose an alternative to classical product classifications; e.g., Nelson's [29] search and experience paradigm. We use the classification scheme for classifying the studied product types and we also apply concepts from the so called product theory [12], which is further described in the next section. By applying this theory to the electronic commerce context we are expanding the theory into a new area. Knowledge about product characteristics' influence on customer interaction in various phases of electronic commerce enriches and specifies the existing product theory. In order to put this theory contribution into practice, a set of focal questions with the aim to increase product understanding in an electronic commerce setting is formulated. The questions highlight product related issues that are important to consider when deciding communication media in electronic commerce. In order to ground the questions empirically, we have conducted qualitative case studies in two distance selling companies (particularly focusing on customer orders, questions, and complaints). The studied products are garments and music-CDs, which are two very common products in electronic commerce and other distance selling settings, such as mail order. These two products have several differences, which make them interesting to study and contrast.

The paper has the following disposition; after this introduction product theory is introduced and discussed in Section two. In Section three the research design is explained, followed by the empirical case studies in Section four. The findings are categorized by product type and its implications on B2C interaction in electronic commerce. This is further elaborated in Section five, where we discuss similarities and differences between the cases and what issues the product classification helps us to understand. The paper is concluded in Section six where we formulate a set of focal questions that intend to generate deeper product understanding in a certain electronic commerce setting. Some issues for further research are also discussed in this last section. 


\section{Product Understanding}

There are many studies performed within the field of electronic commerce searching for factors that make B2C interaction successful; i.e., beneficial both for customer and company. Many explanations have been given to what really influences customers to go shopping on-line. The experience of trust and the existence of reliable security conditions, fast Internet access, safe payment arrangements, lower prices, etc. have been discussed as variables influencing presumptive customers cf., e.g., [20], [21], [25], [33]. Undoubtedly, these are all important factors to get customers to buy from distance selling companies. Another dominating factor that both [1] and [7] emphasize is product characteristics. De Figueiredo [7] proposes that companies' strategies for e-commerce success should be adjusted to their possibilities to show product quality on the web site in order for the customer to be sure about the quality before purchase.

The product, with its characteristics, has been a well-studied phenomenon in, e.g., marketing research for a long time. The seminal work of Nelson [29], [30] introduces the search versus experience paradigm for product classification. In short the paradigm implies this division between product attributes [30]: Search products are products where full information about major product attributes can be obtained by the customer before the purchase. Examples of such products include furniture and garments [17]. Experience products are products where information about major attributes cannot be obtained without direct experience of the product or where the information search is more costly or difficult than direct experience of the product. Examples of such products are vacations and restaurants [17]. Nelson's paradigm has been the basis for many succeeding studies. Darby and Karni [6] added the credence attribute to the classification, which is defined as attributes that the customer cannot verify even after using the product; for example legal services or education [17]. All products can be placed on a continuum depending on how difficult it is to find product information to evaluate before the purchase. The classification of search, experience (and credence) products is made based on where on this continuum the product is placed [29], [30].

Poon and Joseph [32] add the notion of tangible and intangible products to the search and experience paradigm, resulting in a matrix where experience and search products can be either tangible or intangible. Peterson et al. [31] argue for a classification scheme that is supposed to be more relevant to the Internet context. They distinguish between three dimensions of products;

- $\quad$ Cost and frequency - ranging from low cost and high frequently purchased products to high cost and infrequently purchased products

- Value proposition - tangible and physical products vs. intangible and service related products

- Degree of differentiation - high or low degree of sustainable competitive advantage through differentiation

Klein [22] also uses the search and experience paradigm in order to propose a model of consumer information search that integrates the principles of information economics and goods classification. The aim of her research is to understand how interactive media can influence consumer information search before purchase. The fact that Internet changes some preconditions compared to the original way of distinguishing between search and experience products is interesting for our study. In one way, Internet may increase the customers' opportunities to find prepurchase information, for example, by using search engines to find lowest price, customer judgments or detailed product information. In our empirical examples this relates to the music-CDs that are more easily evaluated before purchase on Internet than in a physical store. The customer can listen to the music on-line, read judgments from other customers and so on. This implies that an increased information symmetry between companies and customers would be the result [17]. Some products would, thus, be moved along the search/experience continuum and might become search products thanks to these possibilities of the Internet. In another way, Internet as a communication medium also decreases the possibilities of searching for pre-purchase information in some cases. It is, for example, much easier to gather information about garments in a physical store, where the garment can be tried on, compared and evaluated. When the garment instead is purchased on Internet it is much more difficult to gather this information (which the example in the introduction stated). Typical search products are then moving along the continuum and become experience products instead.

Undoubtedly, the search and experience classification is a mature line of thinking which helps us to make distinctions and categorizations of products. It focuses much on product information, i.e., information that the customer might use for his or her purchase decision. Product information is, as we regard it, one important theme for B2C interaction. However, there is a risk that we neglect the customer's actions and mainly focus on the company's actions (as in marketing activities), if product information is the only focused theme. This would be unfortunate since one-way business actions are not enough - we need interaction between customers and suppliers in order to reach electronic commerce situations that are apprehended as successful by the customer and the company.

This implies that an important thesis in this paper is that we need to understand the characteristics of the product sold by a distance selling company, in order to design a suitable communication media portfolio for B2C interaction. A common way of distinguishing between products, besides the search and experience paradigm, is the classical 
division between goods and services. The customer either buys a physical product (a "thing") or an immaterial "assistance" of some kind. In, e.g., service marketing, researchers study the characteristics of services in comparison to the characteristics of goods [14]. Grönroos [14] defines services to be intangible (immaterial), inseparable in production and consumption, heterogeneous and perishable (i.e., having no separate and lasting evidence).

\subsection{A Pragmatic Product Theory}

Another way of defining product characteristics is introduced by Goldkuhl and Röstlinger [12]. They regard the classical division of goods and services as insufficient and, instead, they propose that the notion of action is important when characterizing goods and services. They base their objections on a pragmatic perspective, which means that actions are performed by an actor who has certain intentions [38]. Each action results in something. There are material actions which give rise to material results, other actions are of a communicative nature and many actions are social to their character. This means that the actions are directed towards other persons. Goldkuhl and Röstlinger [12] claim that we need a more detailed division of products - it is not enough just to distinguish between goods and services. This is also in line with Poon and Joseph [32], who argue that a more fine-grain framework for examining product characteristics is needed in order to fully understand the benefit of electronic commerce for, in their case, small companies.

Using a pragmatic perspective, as Goldkuhl and Röstlinger do, has certain consequences for information systems research. Goldkuhl [10] articulate six aspects that distinguish pragmatic research; an interest for actions, an interest for actions in their practice context, an acknowledgement of action permeation on knowledge, an interest for practical consequences of knowledge, an interest in what works and what does not work, and an acknowledgement of the full dialectics between knowledge and action; i.e., proper action is knowledgeable action and proper knowledge is actable knowledge [10]. The need for pragmatism in information systems research is also emphasized by Goles and Hirschheim [13].

Based on the pragmatic perspective, Goldkuhl and Röstlinger [12] develop a product classification scheme consisting of four main product classes and eight sub-classes:

- $\quad$ Provided goods

- Goods for transfer

- $\quad$ Temporarily provided goods

- $\quad$ Treatment

- Treatment of client's property

- $\quad$ Treatment of client

- Transportation

- Transportation of client's property

- Transportation of client

- Presentation

- Exhibition of goods

- Presentation of producer

This classification builds on the notion that both goods and services might have either a material or an immaterial character; i.e. there are material and immaterial goods as well as services. It also builds on a division between four use situations; material use, informative use, experiential use, and financial use, in order to characterize differences in anticipated customer use and potential satisfaction. Goldkuhl and Röstlinger claim these to be generic producing acts and products. [12]

If we relate Goldkuhl's and Röstlinger's classification scheme to the search and experience paradigm by Nelson and other scholars, it is obvious that there can be both search and experience attributes found in these four product classes. There are, however, more examples of search products in the product class of provided goods and more examples of experience products in the three other product classes. In the financial use situation we find many examples of credence products [6]. The division between tangible and intangible products [32] is also applicable to 
the classification scheme, where treatments, transportations, and presentations are intangible products (i.e., services). This implies that these two ways of classifying products are not contradictory. Instead, they are two approaches that might be used to complement each other.

In table 1, below, the product classification scheme is illustrated with examples of each class. It is important to bear in mind that the product classes are ideal types, which means that in reality many products are multi-functional, since they fulfil several purposes [12]. Later in the paper we will return to this scheme when classifying the studied product types.

Table 1: Product Classification Scheme [12] p. 8

\begin{tabular}{|c|c|c|c|c|}
\hline & Material & Informative & Experiential & Financial \\
\hline Goods for transfer & $\begin{array}{l}\text { Goods purchased for } \\
\text { material use }\end{array}$ & Purchased textbook & $\begin{array}{l}\text { Purchased video } \\
\text { film (action) }\end{array}$ & $\begin{array}{l}\text { Goods/financial } \\
\text { means purchased in } \\
\text { purpose of } \\
\text { exchange/returns } \\
\text { Bond }\end{array}$ \\
\hline $\begin{array}{l}\text { Temporarily } \\
\text { provided goods }\end{array}$ & $\begin{array}{l}\text { Goods rented/ } \\
\text { borrowed for material } \\
\text { use } \\
\text { Rented car, rental of } \\
\text { washing facilities for } \\
\text { car }\end{array}$ & \begin{tabular}{|l|} 
Goods rented/ \\
borrowed for \\
informative use \\
Book (non-fiction) \\
borrowed from library
\end{tabular} & $\begin{array}{l}\text { Goods rented/ } \\
\text { borrowed for } \\
\text { experiential use } \\
\text { Rented video film, } \\
\text { game session in } \\
\text { squash hall }\end{array}$ & $\begin{array}{l}\text { Goods/financial } \\
\text { means borrowed in } \\
\text { purpose of } \\
\text { exchange/returns } \\
\text { Loan of money }\end{array}$ \\
\hline $\begin{array}{l}\text { Treatment of } \\
\text { client's property } \\
\text { Example }\end{array}$ & $\begin{array}{l}\text { Clients' property } \\
\text { treated with material } \\
\text { aim } \\
\text { Car repair service }\end{array}$ & $\begin{array}{l}\text { Clients' property } \\
\text { treated with } \\
\text { informative aim } \\
\text { Auditing, vehicle test }\end{array}$ & $\begin{array}{l}\text { Clients' property } \\
\text { treated with } \\
\text { experiential aim } \\
\text { Copying of photos } \\
\text { or film }\end{array}$ & $\begin{array}{l}\text { Clients' property } \\
\text { treated with financial } \\
\text { aim } \\
\text { Stock administration }\end{array}$ \\
\hline Treatment of client & $\begin{array}{l}\text { Client treated for } \\
\text { physical effect } \\
\text { Eye operation }\end{array}$ & $\begin{array}{l}\text { Client treated for } \\
\text { increase in } \\
\text { knowledge } \\
\text { Eye examination, } \\
\text { training } \\
\end{array}$ & $\begin{array}{l}\text { Client treated for } \\
\text { experiential } \\
\text { enhancement } \\
\text { Psychotherapy }\end{array}$ & $\begin{array}{l}\text { Client treated for } \\
\text { economic influence } \\
\text { Personal insurance }\end{array}$ \\
\hline $\begin{array}{l}\text { Transportation of } \\
\text { client's property }\end{array}$ & $\begin{array}{l}\text { Client's property/ } \\
\text { material transported } \\
\text { with material } \\
\text { purpose } \\
\text { Transportation of } \\
\text { furniture }\end{array}$ & $\begin{array}{l}\text { Client's property/ } \\
\text { information } \\
\text { transported with } \\
\text { informative purpose } \\
\text { Telephony, mail, e- } \\
\text { mail, telefax }\end{array}$ & $\begin{array}{l}\text { Client's property/ } \\
\text { information } \\
\text { transported with } \\
\text { experiential } \\
\text { purpose } \\
\text { Telephony, mail, e- } \\
\text { mail, telefax }\end{array}$ & $\begin{array}{l}\text { Client's property/ } \\
\text { financial means } \\
\text { transported with } \\
\text { economic purpose } \\
\text { Order for payment, } \\
\text { withdrawal from } \\
\text { account }\end{array}$ \\
\hline $\begin{array}{l}\text { Transportation of } \\
\text { client } \\
\text { Example }\end{array}$ & $\begin{array}{l}\text { Client transported } \\
\text { with the purpose to } \\
\text { change location } \\
\text { Bus journey }\end{array}$ & $\begin{array}{l}\text { Client transported } \\
\text { with informative } \\
\text { purpose } \\
\text { Driving lesson }\end{array}$ & $\begin{array}{l}\text { Client transported } \\
\text { with experiential } \\
\text { purpose } \\
\text { Cruise } \\
\end{array}$ & \\
\hline Exhibition of goods & & $\begin{array}{l}\text { Goods exhibited with } \\
\text { informative purpose } \\
\text { Television broadcast } \\
\text { documentary }\end{array}$ & $\begin{array}{l}\text { Goods exhibited } \\
\text { with experiential } \\
\text { purpose } \\
\text { Art exhibition, } \\
\text { entertainment film } \\
\end{array}$ & \\
\hline $\begin{array}{l}\text { Presentation of } \\
\text { producer }\end{array}$ & & $\begin{array}{l}\text { Producer } \\
\text { presentation with } \\
\text { informative purpose } \\
\text { Lecture given by } \\
\text { public lecturer }\end{array}$ & $\begin{array}{l}\text { Producer } \\
\text { presentation with } \\
\text { experiential } \\
\text { purpose } \\
\text { Theatre } \\
\text { performance } \\
\end{array}$ & \\
\hline
\end{tabular}

The main motive for us to use Goldkuhl's and Röstlinger's product classification scheme is that we find their pragmatic arguments attractive since we agree on the notion of actions as important objects to focus on, in order to understand situations and contexts. In the business context studied here, actions and interaction in different business phases are central. Generic phases of a business transaction are; the proposal, commitment, fulfilment, and assessment phases [11]. In Goldkuhl and Lind [11] these business transaction phases are discussed in terms of a generic model for business actions. The basic standpoint of the classification scheme is the two actor roles of the producer and the customer. The producer performs actions that result in a product, intended for the customer. The 
customer performs actions of consumption when receiving and using the product. There will be customer effects of the product and its use; the customer might be satisfied or not. There might also be producer effects when the acts, the results, and the customer reactions retroact on the producer, which is an example of the reflexive and learning aspect of action. [12]

\section{Research Design}

We have performed two qualitative, interpretive case studies, e.g., [39] in distance selling companies in order to inductively explore how these companies' products (garments and music-CDs) influence customer interaction through several communication media. These case studies were performed within a research project that was running from 2000 until 2007. The main purpose of the research project has been to identify which opportunities and hindrances customers and companies experience when using different media for business communication. The main research question in this project has been "How can distance selling companies make well-grounded decisions about which communication media to offer their customers, to improve their customer communication?". This understanding is important in order to guide companies in their efforts to explore opportunities and avoid hindrances when choosing communication media. This paper contains results in accordance with this overall purpose of the project, but it is of course accompanied by other results as well.

In order to collect data about the studied companies and their customers; the way they communicate, their experiences and opinions of customer interaction, etc. we have used several data collection methods. As we use a qualitative research approach, we performed qualitative, open-ended interviews with several actor groups within the studied organizations. We also conducted observations at the customer service departments, which were focused on customer interaction through the present communication media. In order to contrast our deep focus on a small amount of interviewees with a broader view of customer opinions, we also used questionnaires in both the case studies. The questionnaires were sent to a customer population and included both pre-defined and open-ended questions. Finally, we examined texts in different documents; e.g., company publications, marketing documents, and policy documents as well as e-mails from customers. This was done in order to get a view of official statements from the companies as well as an understanding of customer initiated questions and complaints. Data collected by different methods has been contrasted and compared during our data analysis. This method triangulation [8] has been used to get a truthful view of both the companies' and the customers' perspectives on customer communication. Method triangulation is important for validation of results, since weaknesses in one data collection method is compensated by strengths in another used method [8].

In both case studies, the data collection started with interviews with the managers of the customer service departments. These interviews were followed by interviews with the customer service employees. The interviews followed an interview guide with open questions covering several issues; e.g., time allocation between the different communication media the company offers, priorities made between the communication media, the degree of cost efficiency, time consumption, problems, etc. for each communication medium, and positive and negative aspects related to each communication medium. The interviews were held with one interviewee at a time, except for one interview where two persons participated. The interviews were taped and each interviewee was informed that the answers would be treated anonymously.

Observations were conducted at the customer service department, where employees were attending different communication media during their interaction with customers. The observations entailed listening to telephone calls from customers, observing the registration of order forms and answering of e-mails as well as letters and faxes. The researchers were possible to ask questions to the employees about observed events during the observations, but they were not participating in the customer interaction. Notes were taken during the observations. As the questions, asked during the observations, were posed in the working environment they complemented the prepared question guide used during the interviews. The observations were followed by further interviews with the managers of the customer service departments as well as interviews with employees. These, in turn, were followed by new observations and so on until saturation was reached [24], i.e., a situation where new data did not add any significant further findings. We also interviewed IT personnel at the garment company. Unfortunately, we did not get the opportunity to do that at the CD company, because the IT personnel was hired from an external company in that case.

In the first case study (the CD Company) we observed the employees when they were answering e-mails, but in the second case study (the Garments Company) we wanted to perform a deeper analysis of e-mails from customers and the company's answers. Thus, e-mail conversations between customers and employees were collected and analysed in order to get a thorough understanding of what kind of problems and questions a customer might have before, during, and after the purchase, as well as how the company handles this customer-initiated communication. The Garments Company provided us with data files with all e-mail communication from a common week (without any extraordinary events; e.g., the release of a new product catalogue) and we randomly chose to analyse e-mails from one day in this week. This day the company got 561 e-mails, of which 142 were closer examined.

Besides analysing e-mails from the customers, a questionnaire was used in both cases to further explore the customers' perspective on communication. The questionnaire was sent to 100 customers at the CD Company, 
resulting in a $40 \%$ response rate. At the Garments Company we, therefore, decided to increase the amount of questionnaires to 200 . However, the response rate turned out to be the same $(40 \%)$ in this case as well. The questionnaire consisted of 20 questions about the customer's preferences regarding different communication media when communicating with the company in a certain matter (i.e., placing orders, posing questions, and making complaints). Selection criteria for the questionnaire respondents were that they should have been customers for more than two years, made at least one purchase during the four months prior to the questionnaire and at least two purchases during the previous year. Some of the questions in the questionnaire had predefined options and, in order to give the respondents the possibility to express themselves more freely, some questions were open-ended [28]. The questions aimed to explore the reasons behind the customer's choices of communication media. Customers who had, e.g., used e-mail to contact the company were asked to state the reasons for this choice. For each communication medium, the same questions were posed; the favoured medium used for different communicative actions and the reasons behind this were asked for. Data from the questionnaires was analysed in a qualitative way according to our interpretive research approach [39].

All our empirical findings have been analyzed in a way that has been inspired by a grounded theory approach [35]. Interview statements, notes from observations, questionnaire results, e-mail texts, and texts in official documents have been analyzed by using the process of open and axial coding. Findings have been compared and analyzed in order to find common patterns and explanations. Besides this empirical data analysis we have also used product theory to theoretically ground and challenge our findings. Our research method can be related to Klein's and Myer's [23] principles for interpretive field research within the information systems field. We have, e.g., been iterating between parts and the whole in our case studies when analyzing data from different sources, and we have made multiple interpretations possible by interviewing several persons at the customer service department about the same issues. We have also been aware of the importance of looking for contradictions between empirical findings and applied theories. All of this is argued by Klein and Myer [23] to be important for the quality of interpretive, qualitative studies. In table 2, below, the data collection methods and data volumes are summarized.

Table 2: Data Collection

\begin{tabular}{|l|l|l|l|}
\hline $\begin{array}{l}\text { Data collection } \\
\text { methods }\end{array}$ & Respondents/sources & CD Company & Garments Company \\
\hline Interviews & $\begin{array}{l}\text { Managers at customer } \\
\text { service department }\end{array}$ & $\begin{array}{l}3 \text { interviews (1-2 hours } \\
\text { each) }\end{array}$ & $\begin{array}{l}2 \text { interviews (1-2 hours } \\
\text { each) }\end{array}$ \\
\hline Interviews & $\begin{array}{l}\text { Employees at customer } \\
\text { service department }\end{array}$ & $\begin{array}{l}4 \text { interviews (1-2 hours } \\
\text { each) }\end{array}$ & $\begin{array}{l}3 \text { interviews (1-2 hours } \\
\text { each) }\end{array}$ \\
\hline Interviews & IT personnel & - & $\begin{array}{l}2 \text { interviews (1-2 hours } \\
\text { each) }\end{array}$ \\
\hline Observations & $\begin{array}{l}\text { Employees at customer } \\
\text { service department }\end{array}$ & 16 hours & 12 hours \\
\hline Questionnaires & Customers & $\begin{array}{l}40 \text { questionnaires (40\% } \\
\text { response rate) }\end{array}$ & $\begin{array}{l}80 \text { questionnaires (40\% } \\
\text { response rate) }\end{array}$ \\
\hline $\begin{array}{l}\text { Observed } \\
\text { telephone calls }\end{array}$ & Employees \& customers & 67 telephone calls & 34 telephone calls \\
\hline $\begin{array}{l}\text { Analysed e- } \\
\text { mails }\end{array}$ & Employees \& customers & - & $\begin{array}{l}561 \text { e-mails of which 142 } \\
\text { were closer examined }\end{array}$ \\
\hline $\begin{array}{l}\text { Document } \\
\text { studies }\end{array}$ & $\begin{array}{l}\text { Written information (on } \\
\text { paper and IT-based) }\end{array}$ & $\begin{array}{l}\text { Product catalogues, } \\
\text { marketing documents, web } \\
\text { site, communication } \\
\text { statistics, standard e-mail } \\
\text { responses, etc. }\end{array}$ & $\begin{array}{l}\text { Product catalogues, } \\
\text { marketing documents, web } \\
\text { site, communication } \\
\text { statistics, standard e-mail } \\
\text { responses, etc. }\end{array}$ \\
\hline
\end{tabular}

\section{Empirical Cases}

In this section we introduce the two studied companies, including the business model and the offered communication media for each company. We also classify the two product types and report on our empirical findings regarding B2C interaction.

\subsection{The CD Company}

The case study at the CD Company was carried out between fall 2000 and spring 2002. The CD Company is a retailer, selling music-CDs on the Swedish and the Norwegian markets. The company was founded by the present 
CEO some thirty years ago and is now a subsidiary in a corporation with several mail order companies in several European countries. The company has approximately 30 employees.

To purchase from the company, customers are required to register and become members of a customer club. All members receive a monthly magazine with a mandatory offer. The customers will receive the offer if they do not turn it down before a certain date. Customers can also order other products, which are offered in the magazine and on the company's web site. The CD Company offers their customers the following communication media; telephone, fax, letter, membership coupons and order forms, e-mail, voice response system, and the company's web site.

Some of these media are offered for any business action and other media are dedicated for placing orders and turning down the offer of the month. In table 3, below, we illustrate each communication medium's different usage possibilities in a business action matrix. This type of business action matrix was introduced by Johansson and Axelsson [18]. It builds upon the generic phase model of business actions by Goldkuhl and Lind [11]. The matrix illustrates the communication media accessible for the different studied business actions (conducted in different phases of a business transaction). It also illustrates which communication media that are preferred by customers and company as well as which media that are non-preferred (although still offered) by the company. The last alternative was not relevant in this case. The preferences result from our analyses of empirical data.

Table 3: Business Action Matrix of the CD Company

\begin{tabular}{|c|c|c|c|c|c|c|c|}
\hline & Telephone & Fax & Letter & $\begin{array}{l}\text { Membership } \\
\text { coupons, order } \\
\text { forms }\end{array}$ & E-mail & $\begin{array}{l}\text { Voice } \\
\text { response } \\
\text { system }\end{array}$ & Web site \\
\hline $\begin{array}{l}\text { Placing } \\
\text { order }\end{array}$ & $\sim$ & $\sim$ & $\sim$ & $\sim$ & $\sim$ & $\sim \oplus \boldsymbol{\theta}$ & $\sim \odot$ \\
\hline $\begin{array}{l}\text { Turning } \\
\text { down } \\
\text { mandatory } \\
\text { offer }\end{array}$ & $\sim$ & $\sim$ & $\sim$ & $\sim$ & $\sim$ & $\sim \oplus$ & $\sim(;)$ \\
\hline $\begin{array}{l}\text { Posing } \\
\text { questions }\end{array}$ & $\sim$ & $\sim$ & $\sim$ & & $\sim 0$ & & $\sim 0$ \\
\hline $\begin{array}{l}\text { Making } \\
\text { complaints }\end{array}$ & $\sim \rightarrow 0$ & $\sim$ & $\sim$ & & $\sim$ & & \\
\hline
\end{tabular}

Media accessible for each business action ( ), media preferred by customers $(\odot)$, and company $(\boldsymbol{( \boldsymbol { D } )})$, and media non-preferred by company $(\phi)$

\subsubsection{Product Classification of Music-CDs}

The company sells music-CDs; a product that according to the product classification scheme [12] has a prime classification as goods purchased for experiential use. This means that even though the CD is a material product, it is not until the moment when the customer listens to the music that he or she gets any real use of the product. The customer experiences something when listening; he or she is either pleased or dissatisfied with the outcome. On the other hand, when reading the CD cover the customer might use the product in an informative way (answering questions such as "when was this CD produced?" and "who wrote this song?"). A very rare, valuable CD might also be used in a financial way if it is bought as an investment (but the CD Company does not sell that kind of valuable CDs). The music-CD is a standardized product; i.e., each item of a certain CD is identical and there are no ways for customers to influence the product. According to the search versus experience paradigm [29], [30] CDs are classified as a search product. Using the classification scheme adjusted to the Internet context [31], CDs are low cost and high frequently purchased, tangible and physical products with low degree of sustainable competitive advantage through differentiation.

\subsubsection{Communication Media Portfolio}

As shown in table 3, above, customers and company share preferences regarding most communication media. Both customers and employees at the CD company find the process of ordering or turning down the mandatory offer easy to perform through an automated medium (voice response system or web site). There are also some different opinions, for example, that the company prefers customers' questions posed in e-mails or answered by FAQs at the web site, while many customers like to talk to a person on the telephone when having questions. As music-CDs are a rather uncomplicated product the questions are often not so complex, which might be a reason for the company's preference in this matter. Easy, frequently asked questions can, for example, be answered by FAQs at the web site or by standardized answers if posed in e-mails, which is an effective and cost-saving way to work at the customer service department. Both employees and customers agree on the telephone as being the favourable medium for handling complaints. Customers appreciate the notion of someone listening and taking care of their claim 
immediately when they speak to the employees at the customer service department. Among the employees it is also considered easier to "turn" negative customers while they are talking to them.

The standardized and simple product type could also imply that it would be possible for the CD Company to use automated and/or digital media to a higher extent. Even though the company prefers automated media for some business actions (such as placing orders and turning down the mandatory offer), there are reasons for the company to offer as many different communication media as it does. The customers are, for example, a heterogeneous group where many individuals do not have access to Internet at home. The company is aware of the benefits of automated media for its own efficiency, but cares for the customers' needs as well. They regard customer service as their main competitive characteristic. At the same time the company offers more products on the web site than in the monthly magazine, which is a way to steer the customers to this communication medium.

Product information is often limited in many distance communication media compared to a physical store, but in the CD Company there is an example of the opposite as well. Through the voice response system it is possible for the customers to listen to music over the telephone before ordering, which is an example of richer product information than is normally possible to get. This can be related to Klein's study [22] of how Internet alters the possibilities for customers' information search and moves a product along the search/experience continuum.

\subsubsection{B2C Interaction - Examples of Customer Communication}

In table 4, we have gathered some examples of customers' product related questions found during our analysis of the questionnaires and observations at the CD Company. We have also characterized the type of communication according to which business action the customer performs, where this action is placed in the B2C interaction (i.e., in a certain phase of the business transaction), which main aspect the customer discusses and if this aspect is product dependent or not.

Table 4: Empirical Examples of Customer Communication at the CD Company

\begin{tabular}{|c|c|c|c|}
\hline $\begin{array}{l}\text { Customer } \\
\text { communication }\end{array}$ & Business action & $\begin{array}{l}\text { Placement in the } \mathrm{B} 2 \mathrm{C} \\
\text { interaction }\end{array}$ & $\begin{array}{l}\text { Main aspect } \\
\text { discussed }\end{array}$ \\
\hline \multirow{3}{*}{$\begin{array}{l}\text { "I have listened to the } \\
\text { song 'Dark eyes' on the } \\
\text { radio. I think it is a group } \\
\text { called 'The Wall' who } \\
\text { plays it. Do you sell this } \\
\text { CD?" }\end{array}$} & \multirow[t]{3}{*}{ Question } & \multirow[t]{3}{*}{ Proposal phase } & Product mix \\
\hline & & & $\begin{array}{l}\text { Information about } \\
\text { offered products }\end{array}$ \\
\hline & & & Product dependent \\
\hline \multirow{2}{*}{$\begin{array}{l}\text { "I ordered products from } \\
\text { you two weeks ago but I } \\
\text { have not got any delivery } \\
\text { yet. How long will it take?" }\end{array}$} & \multirow[t]{2}{*}{ Question } & \multirow[t]{2}{*}{ Fulfilment phase } & Delivery time \\
\hline & & & $\begin{array}{l}\text { Product dependent or } \\
\text { independent }\end{array}$ \\
\hline \multirow{3}{*}{$\begin{array}{l}\text { "I got the delivery from } \\
\text { you yesterday, but it was } \\
\text { the wrong CD in the } \\
\text { parcel. What shall I do?" }\end{array}$} & \multirow{3}{*}{$\begin{array}{l}\text { Complaint (expressed as a } \\
\text { question) }\end{array}$} & \multirow[t]{3}{*}{ Assessment phase } & Reclaim of product \\
\hline & & & Delivery mistake \\
\hline & & & Product independent \\
\hline \multirow{3}{*}{$\begin{array}{l}\text { "I have received the } \\
\text { mandatory offer of the } \\
\text { month, even though I } \\
\text { have cancelled this. What } \\
\text { shall I do?" }\end{array}$} & \multirow{3}{*}{$\begin{array}{l}\text { Complaint (expressed as a } \\
\text { question) }\end{array}$} & \multirow[t]{3}{*}{ Assessment phase } & Reclaim of product \\
\hline & & & $\begin{array}{l}\text { Breakdown in business } \\
\text { communication }\end{array}$ \\
\hline & & & Product independent \\
\hline
\end{tabular}

As shown in table 4 above, there are several examples of customer initiated communication that can be characterized as product independent in this case. These chosen examples are corresponding with the total picture of this case study.

\subsection{The Garments Company}

The case study at the Garments Company was carried out in 2004. The Garments Company is a retailer, selling garments, furniture and other home articles in Sweden and in two other countries in northern Europe. The company was founded about 50 years ago and is now a subsidiary in a corporation with several mail order companies in Europe. The company has approximately 250 employees.

The Garments Company started as a traditional mail order company and is still exposing its products in two large product catalogues published in the spring and autumn seasons every year. The company has, however, adopted 
new communication possibilities and offers their customers the following communication media; telephone, fax, letter, order forms, e-mail, voice response system, and the company's web site.

All communication media can be used to place orders whereas posing questions and making complaints is only possible through some of them. In table 5, below, we illustrate each communication medium's different usage possibilities in a business action matrix [18]. The matrix illustrates the communication media accessible for the different studied business actions. It also illustrates which communication media that are preferred by customers and company as well as which media that are non-preferred (although still offered) by the company. The preferences result from our analyses of empirical data.

Table 5: Business action matrix of the Garments Company

\begin{tabular}{|c|c|c|c|c|c|c|c|}
\hline & Telephone & Fax & Letter & Order forms & E-mail & $\begin{array}{l}\text { Voice } \\
\text { response } \\
\text { system }\end{array}$ & Web site \\
\hline Placing order & $\sim \oplus$ & $\sim$ & $\sim$ & $\sim$ & $\sim \phi$ & $\sim$ & $\sim \oplus$ \\
\hline $\begin{array}{l}\text { Posing } \\
\text { questions }\end{array}$ & $\sim \oplus \boldsymbol{O}$ & $\sim$ & $\sim$ & & $\sim$ & $\sim \boldsymbol{0}$ & $\sim$ \\
\hline $\begin{array}{l}\text { Making } \\
\text { complaints }\end{array}$ & $\sim \oplus$ & $\sim$ & $\sim$ & & $\sim \phi$ & & \\
\hline
\end{tabular}

Media accessible for each business action ( ), media preferred by customers $(\odot)$, and company $(\boldsymbol{(})$, and media non-preferred by company $(\phi)$

\subsubsection{Product Classification of Garments}

The company sells garments; a product that according to the product classification scheme [12] has a prime classification as goods purchased for material use. The garments, a pair of jeans, for example, are used in a material way in order to keep the bearer warm. Nevertheless, there can also be an experiential aspect of this product, e.g., if the customer wears jeans of a certain brand. The experiential side can have several expressions; the jeans indicates that the customer knows what is the latest fashion, that he or she is wealthy enough to buy a certain brand, that he or she belongs to a special group of people, and so on. This means that the pair of jeans that keeps a person warm was bought for material use, but they might also satisfy other, experiential goals. This is an example of the several use dimensions that a product may have, according to product theory [12]. The customer might be satisfied with the material function of the garments ("these clothes have the right size and I don't freeze"), but he or she can also be satisfied with the experiential use ("these clothes really make me look fabulous"). If the customer instead buys a celebrity's worn boots, it could be regarded as a financial use aspect, in case it is a valuable object for collectors that might be sold with profit later on. This case is, however, not applicable on the Garments Company. Garments as products are standardized, but they come in several sizes and colours, which makes it necessary for customers to make several decisions based on product information, besides whether they want to buy the item or not. According to the search versus experience paradigm [29], [30] garments are classified as a search product. As stated by Klein [22] garments is an example of a product which is more difficult to gather purchase information about when offered on Internet compared to a physical store; i.e., it moves on the search/experience continuum when offered via this medium. Using the classification scheme adjusted to the Internet context [31], garments are low cost and high frequently purchased, tangible and physical products with low degree of sustainable competitive advantage through differentiation.

\subsubsection{Communication Media Portfolio}

In the Garments Company employees and customers to a high extent share the same opinion regarding preferred media. Telephone is, for example, preferred by many respondents for all studied business actions. This might seem odd for a company in the electronic commerce market. Thus, this must be understood in the light of the product type as well as the customer group's characteristics. Customers pose many questions about colours, sizes, fabrics, etc. that are related to garments as a product type. These questions are apprehended by the employees as easier to answer over telephone than through other media. The customers are a more homogenous group compared to the customers at the CD Company. There are a lot of women in the age between 30 and 50, and many of them state that they are more comfortable talking on the telephone than using other communication media. The same fact is valid for the employees at the customer service department, who also like to talk on the telephone. Some of the interviewees at the customer service department strongly emphasize a negative attitude towards answering e-mails, for example. The same employees regard talking on the telephone as one of the most appreciated aspects of their job.

Besides telephone, the company also prefers questions to be solved by the voice response system. There are, however, only a few questions which can be answered this way (e.g., information about returned products and last 
conducted payment). This medium does not provide any feedback to the customers, which is another reason why customers do not appreciate the voice response system compared to the other offered media. Placing order through the web site is appreciated by both the company and some customers (i.e., customers with Internet access).

Even though the employees do not prefer e-mail conversations if they may choose, the company still offers this communication medium. There are several reasons for this; first of all the reluctance towards e-mails is expressed by the employees at the customer service department, not by the managers. The employees express their negative attitude towards e-mail communication in relation to their work situation, while managers might appreciate the efficiency in IT or the higher level of customer service more. The company also acknowledges that some customers are used to e-mail and expect it to be an option when communicating with the company.

To summarize, there seem to be two factors, both the product type and reluctance towards the use of e-mail among both customers and employees, that together result in this opinion. Another mentioned reason for the company to prefer telephone communication is the opportunity for increased extra selling that the telephone implies. Many customers who call the company to order one product accept additional offers while talking to the employee, for example, an offer to buy a T-shirt to reduced price when ordering a skirt. This behaviour can be related to the product type; it is rather usual to buy more than one garment at the same time when shopping in physical stores, but much more unusual when buying a journey, for example. The employees do not experience that this opportunity to extra-selling is apparent to the same extent in the other communication media.

\subsubsection{B2C Interaction - Examples of Customer Communication}

In table 6, below, we have gathered some examples of customers' product related questions found during our analysis of e-mails, the questionnaires, and observations at the Garments Company. We have also characterized the type of communication according to which business action the customer performs, where this action is placed in the B2C interaction (i.e., in a certain phase of the business transaction), which main aspect the customer discusses and if this aspect is product dependent or not.

Table 6: Empirical Examples of Customer Communication at the Garments Company

\begin{tabular}{|c|c|c|c|}
\hline $\begin{array}{l}\text { Customer } \\
\text { communication }\end{array}$ & Business action & $\begin{array}{l}\text { Placement in the } \\
\text { B2C interaction }\end{array}$ & Main aspect discussed \\
\hline \multirow{3}{*}{$\begin{array}{l}\text { "I'm interested in a T-shirt } \\
\text { in cotton with product no. } \\
131334 \text {. You sell this T- } \\
\text { shirt in several colours but } \\
\text { I cannot find any picture } \\
\text { of the blue one at your } \\
\text { web site. Is it light blue or } \\
\text { dark blue?" }\end{array}$} & \multirow[t]{3}{*}{ Question } & \multirow[t]{3}{*}{ Proposal } & Product information \\
\hline & & & $\begin{array}{l}\text { Colour nuance as input to the } \\
\text { purchase decision }\end{array}$ \\
\hline & & & Product dependent \\
\hline \multirow{3}{*}{$\begin{array}{l}\text { "Is it possible to buy a suit } \\
\text { with different sizes on } \\
\text { trousers and coat?" }\end{array}$} & \multirow[t]{3}{*}{ Question } & \multirow[t]{3}{*}{ Proposal } & Business process regulations \\
\hline & & & Difficulty to find right size \\
\hline & & & Product independent \\
\hline \multirow{3}{*}{$\begin{array}{l}\text { "I have already ordered a } \\
\text { pink zip suit to my grand- } \\
\text { daughter and want to buy } \\
\text { a cap and gloves that fit } \\
\text { this. Do you have them in } \\
\text { the same colour? Which } \\
\text { size should I order?" }\end{array}$} & \multirow[t]{3}{*}{ Question } & \multirow[t]{3}{*}{ Proposal } & Product information \\
\hline & & & Colour and size \\
\hline & & & Product dependent \\
\hline \multirow{3}{*}{$\begin{array}{l}\text { "I bought a black sweater } \\
\text { with white printing from } \\
\text { you. I have washed it } \\
\text { twice and now the printing } \\
\text { is all gone. What shall I } \\
\text { do?" }\end{array}$} & \multirow{3}{*}{$\begin{array}{l}\text { Complaint } \\
\text { (expressed as a } \\
\text { question) }\end{array}$} & \multirow[t]{3}{*}{ Assessment } & Reclaim of product \\
\hline & & & Bad product quality \\
\hline & & & Product dependent \\
\hline \multirow{3}{*}{$\begin{array}{l}\text { "I bought a pair of jeans in } \\
\text { my ordinary size from } \\
\text { you, but I cannot get them } \\
\text { over my knees. I want to } \\
\text { return them." }\end{array}$} & \multirow[t]{3}{*}{ Complaint } & \multirow[t]{3}{*}{ Assessment } & Reclaim of product \\
\hline & & & Wrong size \\
\hline & & & Product dependent \\
\hline
\end{tabular}


As shown in table 6 above, there are many examples of customer initiated communication that can be characterized as product dependent in this case. These chosen examples are corresponding with the total picture of this case study.

\section{Analysis of Product Characteristics}

The main question to discuss here is in what way an increased product understanding might help us decide how a distance selling company's customer interaction should be performed. As we stated in the beginning of the paper, there are many aspects that may influence decisions about which communication media to offer the customers. What we are emphasizing here is that the product type affects what kind of communication that will take place between the customer and the company; customer questions will be more or less complex to answer, asked in different phases of the business process, and reflecting different feelings of the customer.

What do we distinguish by using product theory to characterize products? Product theory draws our attention towards certain aspects of products and product use; e.g., levels of product standardization, multi-functionality of product use and durability of consumption [12]. We will now use these theoretical concepts to discuss our empirical findings. We will also discuss the explanation force of product theory and, finally, examine the importance of product understanding in $\mathrm{B} 2 \mathrm{C}$ electronic commerce.

\subsection{Levels of Product Standardization}

If we look at the two studied product types, music-CDs and garments, both are goods that customers purchase. Both CDs and garments are standardized, but CDs are (normally) fully standardized, i.e., there are no variants of a certain CD. An exception from this is in cases when a musician or a band bring out limited editions of their latest CD, at a higher price but with additional material (music DVDs, for example). Garments, on the other hand, always come in different sizes and are often available in several colours. Thus, there are normally variants of garments within a standardized product type (i.e., colours, sizes). This means that a customer has to make several judgments before the purchase decision. Some judgments are related to the specific product (What kind of textile is it made of? Does it have the right quality? Can I afford it?), some questions are related to the customer (Which size should I order? Can I wear this kind of garment?), and some questions are related to other products (Does it fit with the other colours I use to wear?). In the CD case, the customer only has to make the decision to buy the product or not (Do I like this music? Can I afford this CD?). As we have shown in these examples, the differing product types and levels of standardization influence the customer decisions.

The communication media that the distance selling company offers its customers are very important when it comes to easing or complicating the customer decisions. It would, for example, probably be appropriate for the Garments Company to offer media that enables richness in pre-purchase product information. This could be anything from showing all offered colours at the web site, and give thorough information about how to find the right size, to offering personalized multi-media models to visualize the clothes. This can be related to the discussion, above, on search and experience products [29], [30] and Internet's influence on the continuum between these two types of products [22]. The fact that garments is a less standardized product, compared to music-CDs, can also explain our findings that both customers and employees at the Garment Company prefer telephone communication to a higher extent.

\subsection{Multi-functionality of Product Use}

Product theory makes us focus on use situations; the product is aimed for material, informative, experiential or financial use [12]. This also indicates the multi-functionality of products; a product might be used for several reasons by one customer. This implies that a product can have a prime classification, but also one or several secondary classifications. Even though most products relate to a main use situation, different customers might use identical products for different reasons. In that case, they buy the product with differing purposes. A certain garment would, e.g., be bought for material use by one customer and for experiential use by another customer. The differing use situations imply that the same product has different meanings for these customers. A common example of this is that a product's function and design might be regarded in different ways depending on whether the product is used in a material way ("it is impossible to run in this skirt") or for experiential reasons ("this skirt was made by a famous designer and cost me a fortune"). The degree of satisfaction regarding a certain product might differ radically depending on the intended use situations different customers envision when buying the product.

A distance selling company needs to understand how their products are regarded and used by their customers. This understanding must be reached over distance since they do not normally meet their customers face-to-face. The company has to understand that a certain product might be bought for different use situations, which result in different demands on the customer interaction. This makes the notion of multi-functionality of product use important in $\mathrm{B} 2 \mathrm{C}$ electronic commerce. 


\subsection{Durability of Product Consumption}

When discussing use situations, product theory also directs the attention towards the fact that products will be more or less affected by time [12]. Some products are permanent over time while other products are worn after usage. This is a fact that also influences the business interaction, as we can see in the Garments Company where a customer is complaining about a sweater that has lost its printing after two washes. In product theory this is mentioned as the product's durability of consumption [12], where reuse is a critical dimension. Customers have different expectations regarding how long a certain product will last, depending on what type of product it is, its quality and price, etc. The use situation affects most products, but products might be more or less robust. It is important to be aware of such customer expectations in order to be prepared for customer interaction about these issues and, thus, use feasible communication media for this interaction. The level of a product's standardization also influences how complaints about unfulfilled expectations of a product's durability might be solved. It is easier to replace a product by another as a substitute in some cases than in others.

\subsection{Explanation Force of Product Theory}

As the discussion above has shown, product classification and product theory according to [12] has helped us focus on certain aspects and concepts which have increased our product understanding in the studied cases. The levels of product standardization, multi-functionality of product use, and durability of product consumption are three aspects that we have examined. Product theory acknowledges the co-existence of several product use situations in the same product. This is the reason why we have characterized the studied products as belonging to a prime use situation. The fact that there is no existence of a one-to-one relationship between a certain product and a use situation could be regarded as a weakness of the product classification scheme. One could assume that the theory should consist of clear-cut categories. Instead, we argue that this is in correspondence with the complexity of the product concept in itself. A product needs a user, and since users are human beings with different intentions and interpretations there will always be a complexity regarding how different individuals apprehend a certain product. The product theory recognizes this complexity. The search and experience paradigm [29], [30] handles this complexity by using a continuum instead of classes when classifying products.

We do not see product theory [12] as an opponent to the search and experience paradigm [29], [30]. As we have discussed in this paper, these different theoretical constructs offer complementing understanding to the product context. They focus on different aspects and should, thus, be possible to use together. There is, however, an important issue that needs to be understood before using these theories as complements. Products with high degree of experience attributes [29] and products intended for an experiential use situation is not equivalents. Experience products are products where information about major attributes cannot be obtained without direct experience of the product or where the information search is more costly or difficult than direct experience of the product. Related to product theory [12] most products in the classes of treatment, transportation, and presentation have high degree of experience attributes. Products that are intended for experiential use, according to the four use situations stipulated in product theory [12], could be either search products (e.g., a detective story) or experience products (e.g., a holiday at the Maldives). These two theoretical concepts are unfortunately close to each other, but are used with different definitions in the theories.

\subsection{The Importance of Product Understanding in B2C Electronic Commerce}

If we return to the two cases, we can compare the main aspects that customers discussed. In the CD Company customers' questions reflect the business process in general; what products there are to order, how long the delivery time will be, and how to return products. These are all questions that are common in any distance selling setting and most of them are product independent. In the Garments Company, on the other hand, the customers' questions concern more product dependent aspects; such as product information before an order as well as complaints on product quality and size after delivery. These are examples of the more demanding business decisions that the garment customer has to make and the consequences of making wrong purchase decisions. When deciding which communication media to offer customers it is, thus, important to estimate how much product dependent versus product independent customer interaction there will be.

Another interesting issue in the CD Company is that the business model itself, which implies that a mandatory offer each month has to be turned down in due time (otherwise it will be regarded as accepted), causes questions and complaints. Internet-based companies have the opportunity to design various innovative business models [36]. The business model should be designed in a way that fits the offered product type, of course, but it is also important for the company to understand what kind of customer interaction the business model in itself will result in.

In both our two cases, the companies have chosen to offer their customers a wide range of communication media. We have studied three types of business actions; placing orders, posing questions, and making complaints. As shown in tables 3 and 5 above, the two companies offer the same communication media to their customers even though they sell different types of products. Does this imply that the product does not make any difference when deciding what communication media to offer? We argue that the answer is no. As we regard this circumstance, it is instead an example of how companies do not focus on product characteristics when choosing communication media. 
The two studied companies offer a rather "standardized" variety of media for this kind of distance selling companies. They started as mail order companies and still they use product catalogues and telephone a lot, but the media portfolio has been complemented with some "modern" IT communication artefacts such as e-mail, the web site and the voice response system. Our findings indicate that this has been done more as a consequence of the availability of these media, and the fact that other companies offer them, than as a result of any deeper analysis of the coherence between these media and the offered product type.

As a reaction to this finding, we argue that when a company is about to decide which media to include in the communication media portfolio and which media to leave out, it is vital to analyse not only which media that are available for a certain business action but also to investigate what kind of business interaction the product type might result in. This will help companies to design their customer interaction in a way that meets both the customers' expectations and the company's needs.

All the examples discussed above can be used by companies to get prepared for different customers' situations, needs, and problems. By increasing the product understanding and the notion of how product type influences the $\mathrm{B} 2 \mathrm{C}$ interaction, companies are able to make reflective decisions about how to handle and interact with their customers. Such decisions should not only be made on basis of what is technically possible or what other distance selling companies do. The communication media portfolio should also reflect what kind of products the B2C interaction will be about.

\section{Conclusions and Further Research}

Several theories focus on communication channels when trying to explain business interaction in electronic commerce. Media richness theory [5] is one example. Its purpose is to explain managers' choice of communication media and explore how to make communication more effective by choosing the appropriate communication medium. There are similarities between this theory and our work when it comes to the notion of making feasible choices of communication media. Media richness theory has, however, been criticized for neglecting the fact that there is not one effective way to communicate for all people or in all contexts, e.g., [2], [26], [41]. Instead, the richness of a certain communication medium depends on the user and the use situation. Mattila and Wirtz [27] as well as Fulk et al. [9] show that customers chose communication medium very much depending on their personality, which is in line with our empirical findings. This is important criticism of the media richness theory which we share. In this paper we have argued that an important aspect of the context, in which the business interaction takes place, is the product itself. By using product theory [12] we focus on products instead of media and, thus, avoid being too narrow and context independent in our perspective on choices of communication media.

There are many issues that might influence the design of a communication media portfolio; economy, customer target groups, perspective on customer service, etc. In this paper we argue that product understanding should be added to this list. Our contribution to product theory [12] is that we have specified product characteristics for the electronic commerce context. Product theory has been adopted and validated in this study, but also complemented with the notion of different types of business actions (orders, questions, and complaints) in the various business phases (proposal, commitment, fulfilment, and assessment).

\subsection{Focal Questions on Product Characteristics}

In this section we present a set of questions for companies to answer in order to increase their product understanding when designing a feasible portfolio of communication media for B2C interaction. The questions have been formulated based on core concepts from the product theory [12] as well as empirical findings from our case studies. These questions are, thus, both empirically and theoretically grounded and should be regarded as indicators of aspects that, according to our study, seem to be relevant for B2C interaction in electronic commerce settings. The set of questions, which is this paper's practical contribution, can be used in several ways; for example, as discussion themes in a design or re-design process or as evaluation criteria when assessing the outcome of a certain business model.

\section{What product type(s) do the company offer their customers? How can the products be characterized?}

The product classification scheme [12] helps to characterize the product type in detail. Compared to the rather blunt, common division of goods and services [14], this gives a much more thorough understanding of the offered product's characteristics. A product can be more or less complex in many aspects; e.g., regarding product variation, use situations, product choices, etc [12]. A complex product will probably result in more demanding and distinctive customer questions before, during or after the business transaction. Such questions are most likely more difficult to answer through automated media. Thus, there is a need for more personal (synchronized) contact with customers (without the delay between questions and answers as in e-mail communication, for example) than in cases with less complex products. Our empirical findings have, e.g., shown that garments, as being a less standardized product than music-CDs, tend to generate more product dependent questions in all business phases. 
Are there aspects of several product classes in the products, and if so, in what way?

Even though a product can be placed in a certain product class in the classification scheme, there might be aspects of other product subclasses in this product [12]. This is an example of the sometimes very complex nature of a product. Many products of today are a mixture of goods and services, which indicates that a reflective characterization is needed. Buying a certain music-CD could, e.g., give access to the artist's community on the Internet. A garment could be bought as a present, where the company delivers the garment, wrapped as a gift, to another person than the buyer. These are two examples of services connected to the studied products.

How do the customers use the product and what is the role of the product in this use situation? Are there multifunctional use situations for a certain product?

The notion that a product might be bought and used for several reasons is important. Different customers might buy a product for various purposes, but a customer might also see several use situations for one product [12]. Different use situations give rise to different customer questions. Thus, understanding what kind of situations the offered products can be used in is important when designing how the B2C interaction should be conducted. Questions regarding the use situations of the product as well as complaints about the product or business process might be handled more easily through certain media than through others. A complicated technical artefact that needs to be installed before it can be used, might, for instance, cause complex customer questions that need to be answered through a dialogue on telephone or by using a web-based help system.

Does the business model in coordination with the product type(s) generate any specific problems that customers might contact the company about?

Analysis of factors that result in a B2C interaction that meets both the expectations of the customers and the needs of the company, has to be made with several objects in mind. An isolated critical review of the business model could give us some answers, but when reflecting on the business model in relation to the offered products the outcome would probably be more comprehensive. The result of a certain business model is depending on its context, where the product is one important factor to consider as well as the offered communication media. In the CD Company the business model contains a mandatory monthly offer, which has to be turned down in due time if the customer does not want to buy the product. In this case, there were many customer questions and complaints regarding this model, which had to be handled by the customer service department.

What kind of customer interaction (questions and complaints) do the products mainly generate? Where lays the complexity in the B2C interaction?

The entire business setting might be more or less complex depending on several things; the distance between customer and seller, product type, customer target groups, the business model, etc. Each company has to consider its specific conditions, how their customers usually react in different situations, and so on. The solution is not always to avoid complexity, but to understand the complex challenges and decide how to handle them in an appropriate way. In our two case studies, most complexity was found in the product variation (the Garments Company) and the business model (the CD Company).

What communication media do the company offer the customers and what business actions are possible to perform through each medium?

Besides reaching a good understanding of the product type, the use situations of the customers, the complexity of this certain business interaction, etc., it is also important to explore which business actions the customer performs and through which communication media these actions could and should be performed. Common business actions to perform are, e.g., posing questions, ordering a product, cancelling an order, paying for the product, and making complaints [11]. The question is not which possible media there are to use, but which media that are both possible and feasible to use to perform a particular business action in a certain situation. When making this decision it is vital to both take the customer and the company perspective into account. The communication portfolio needs to be constructed in a way that both meets the expectations of customers and the needs of the company, as stated earlier. Using a business action matrix [18] to analyse the preferences of customers and company is one way of getting this broad view of relationships between communication media and business actions.

\subsection{Further Research}

The questions above are inductively derived from our two qualitative case studies and theoretically grounded in previous product research. In order to further explore the importance of product understanding in $\mathrm{B} 2 \mathrm{C}$ interaction, the questions need to be practically tested in several distance selling settings. There would, for example, be interesting to use these questions as evaluation criteria in a number of electronic commerce companies in order to find out more about how B2C interaction is influenced by product type.

Even though we have focused on product type in this paper, we are aware that product type alone cannot judge which communication media that would be successful in a certain situation. We agree with Poon and Joseph [32] in 
their statement that electronic commerce companies also need to consider other aspects besides product characteristics in order to gain benefit from electronic commerce. Thus, it would be interesting to extend the scope and relate our theoretical contributions regarding product type to theories of other identified aspects. One such issue is discussed by Gutek [15] in his taxonomy of service interaction, where service relationships and service encounters are distinguished. By viewing this classification of different types of linkage between customers and companies, and relating this to the product type, one could maybe expand the notion of product understanding in electronic commerce further.

\section{References}

[1] S. Ba, J. Stallart, A. B. Whinston and H. Zhang, Choice of transaction channels: the effects of product characteristics on market evolution. Journal of management information systems, vol. 21, no. 4, pp. 173-197, 2005.

[2] J. R. Carlson and R. W. Zmud, Channel expansion theory and the experimental nature of media richness perceptions. Academy of Management Journal, vol. 42, no. 2, pp. 153-170, 1999.

[3] D. Chaffey, E-Business and E-Commerce Management. Pearson Education, London, 2002.

[4] P. A. Dabholkar, Technology in service delivery: implications for self-service and service support. In T. A. Swartz and D. lacobucci, (Eds.), Handbook of Services Marketing and Management). Sage publications, Thousand Oaks, CA, pp. 103-110, 2000.

[5] R. L. Daft and R. H. Lengel, Organizational information requirements, media richness and structural design. Management Science. vol. 32, no. 5, pp. 554-571, 1986.

[6] M. R. Darby and E. Karni, Free competition and the optimal amount of fraud. Journal of Law and Economics, vol. 16, no. 1, pp. 67-86, 1973.

[7] J. M. de Figueiredo, Finding sustainable profit in electronic commerce. Sloan Management Review, vol. 41, no. 4, pp. 41-52, 2000.

[8] N. K. Denzin and Y. S. Lincoln, Entering the Field of Qualitative Research, in N. K. Denzin and Y. S. Lincoln, (Eds.): Handbook of Qualitative Research, Sage, 1994.

[9] J. Fulk, J. Schmitz and C. Steinfield, A social influence model of technology use. In J. Fulk and C. Steinfield, (Eds.), Organization and Communication Technology. Sage Publications, Newbury Park, CA, 1990.

[10] G. Goldkuhl, Meanings of Pragmatism: Ways to conduct information systems research. In proceedings of The 2nd International Conference on Action in Language, Organisations and Information Systems (ALOIS 2004). Linköping, Sweden 17-18 March 2004.

[11] G. Goldkuhl and M. Lind, Developing e-interactions - a framework for business capabilities and exchanges, in T. Leino, T. Saarinen and S. Klein, (Eds.) Proceedings of the 12th European Conference on Information Systems (ECIS2004), Turku, Finland, 2004.

[12] G. Goldkuhl and A. Röstlinger, Beyond Goods and Services - An Elaborate Product Classification on Pragmatic Grounds. In proceedings of The Seventh International Research Symposium on Service Quality (QUIS 7), Karlstad, Sweden, June 13-16 2000.

[13] T. Goles and R. Hirschheim, The paradigm is dead, the paradigm is dead... long live the paradigm: the legacy of Burrell and Morgan. Omega, vol. 28, no. 3, pp. 249-268, 2000.

[14] C. Grönroos, Service marketing and management. Managing the moments of truths in service marketing. Lexington Books, Lexington, 1990.

[15] B. A. Gutek, The Dynamics of Service: Reflections on the Changing Nature of Customer/Provider Interactions. Jossey-Bass, San Fransisco, CA, 1995.

[16] J. L. Heskett, T. O. Jones, G. W. Loveman, W. E. Sasser and L. A. Schlesinger, Putting the service-profit chain to work. Harvard Business Review, vol. 72, no. 2, pp. 164-74, 1994.

[17] Y-C. Hsieh, H-C. Chiu and M-Y. Chiang, Maintaining a committed online customer: A study across searchexperience-credence products. Journal of Retailing, vol. 81, no. 1, pp. 75-82, 2005.

[18] B-M. Johansson and K. Axelsson, Analysing Communication Media and Actions - Extending and Evaluating the Business Action Matrix, in D. Bartman, F. Rajola, J. Kallinikos, D. Avison, R. Winter, P. Ein-Dor, J. Becker, F. Bodendorf and C. Weinhardt, (Eds.) Proceedings of the 13th European Conference on Information Systems (ECIS2005), Regensburg, Germany, 26-28 May 2005.

[19] P. Keen, Relationships. The Electronic Commerce Imperative in Information Technology and the Future Enterprise. In G. W. Dickson and G. DeSanctis, (Eds.), New Models for Managers, Prentice Hall, New Jersey, pp. 163-185, 2001.

[20] P. Keen, C. Balance, S. Chan and S. Schrump, Electronic Commerce Relationships - Trust by Design. Prentice Hall, 2000.

[21] K. Kim and B. Prabhakar, Initial trust, perceived risk, and the adoption of Internet banking. In Proceeding of the International Conference on Information Systems (ICIS 2000), pp. 537-543, 2000.

[22] L. R. Klein, Evaluating the potential of interactive media through a new lens: Search versus experience goods. Journal of Business Research, vol. 41, no. 3, pp. 195-203, 1998.

[23] H. K. Klein and M. D. Myers, A set of principles for conducting and evaluating interpretive field studies in information systems. MIS Quarterly, vol. 23, no. 1, pp. 67-94, 1999.

[24] Y. S. Lincoln and E. G. Guba, Naturalistic Inquiry. Sage Publications, 1985.

[25] M. A. Mahmood, K. Bagchi and T. C. Ford, On-line Shopping Behavior: Cross-Country Empirical Research. International Journal of Electronic Commerce. Fall 2004, vol. 9, no. 1, pp. 9-30, 2004. 
[26] M. L. Markus, Electronic Mail as the Medium of Managerial Choice. Organization Science. vol. 5, no. 4, pp 502527, 1994.

[27] A. S. Mattila and J. Wirtz, Consumer complaining to firms: the determinants of channel choice. Journal of Services Marketing, vol. 18, no. 2, pp. 147-155, 2004.

[28] S. B. Merriam, Case Study Research in Education. Jossey-Bass Inc. Publishers, San Francisco, 1988.

[29] P. J. Nelson, Information and consumer behaviour. Journal of Political Economy, vol. 78, no. 2, pp. 311-329, 1970.

[30] P. J. Nelson, Advertising as information. Journal of Political Economy, vol. 82, no. 4, pp. 729-754, 1974.

[31] R. A. Peterson, S. Balasubramanian and B. J. Bronnenberg, Exploring the implications of the Internet for consumer marketing. Journal of the Academy of Marketing Science, vol. 25, no. 4, pp. 329-346, 1997.

[32] S. Poon and M. Joseph, Product characteristics and Internet commerce benefit among small businesses. The Journal of Product and Brand Management, vol. 9, no. 1, pp. 21-34, 2000.

[33] M. E. Porter, Strategy and the Internet. Harvard Business Review, March 2001, pp. 63-78, 2001.

[34] M. Singh, E-services and their role in B2C e-commerce. Managing Service Quality, vol. 12, no. 6, pp. 434-446, 2002.

[35] A. Strauss and J. Corbin, Basics of Qualitative Research: Techniques and Procedures for Developing Grounded Theory. $2^{\text {nd }}$ edition, Sage Publications, Thousand Oaks, CA, 1998.

[36] P. Timmers, Electronic Commerce - Strategies and Models for Business-to-Business Trading. John Wiley \& Sons Ltd, Chichester, 1999.

[37] E. Turban, D. King, J. Lee and D. Viehland, Electronic commerce 2004: A Managerial Perspective. Prentice Hall, Upper Saddle River, NJ, 2004.

[38] G. H. von Wright, Norm and action. Routledge \& Kegan Paul, London, 1963.

[39] G. Walsham, Doing interpretive research. European Journal of Information Systems, vol. 15, no. 3, pp. 320-330, 2006.

[40] S. W. Winer, A framework for customer relationship management. California Management Review, vol. 43, no. 4, pp. 89-105, 2001.

[41] J. Yates and W. J. Orlikowski, Genres of Organizational Communication: An Approach to Studying Communication and Media. The Academy of Management Review. vol. 17, no. 2, pp. 299-326, 1992. 